\title{
Peroxisome proliferators-activated alpha agonist treatment ameliorates hepatic damage in rats with obstructive jaundice: an experimental study
}

\author{
Mehmet Cindoruk ${ }^{\dagger 1}$, Mustafa Kerem* ${ }^{* 2}$, Tarkan Karakan1, Bulent Salman², \\ Okan Akin $^{3}$, Murat Alper ${ }^{4}$, Ozlem Erdem ${ }^{5}$ and Selahattin Ünal ${ }^{1}$
}

Address: ${ }^{1}$ Department of Gastroenterology, Gazi University Faculty of Medicine, Ankara, Turkey, ${ }^{2}$ Department of General Surgery, Gazi University Faculty of Medicine, Ankara, Turkey, ${ }^{3}$ Department of Biochemistry, Kecioren Training and Research Hospital, Ankara, Turkey, ${ }^{4}$ Department of Pathology, Diskapi Training and Research Hospital, Ankara, Turkey and ${ }^{5}$ Department of Pathology, Gazi University Faculty of Medicine, Ankara, Turkey

Email: Mehmet Cindoruk - mcindoruk@gazi.edu.tr; Mustafa Kerem* - mkerem@gazi.edu.tr; Tarkan Karakan - tkarakan@gmail.com; Bulent Salman - bsalman@gazi.edu.tr; Okan Akin - okhanak@yahoo.com; Murat Alper - alpermurat@mynet.com; Ozlem Erdem - oerdem@gazi.edu.tr; Selahattin Ünal - sunal@gazi.edu.tr

* Corresponding author †Equal contributors

Published: 28 November 2007

BMC Gastroenterology 2007, 7:44 doi:10.1 I86/I47|-230X-7-44
Received: 23 January 2007

Accepted: 28 November 2007

This article is available from: http://www.biomedcentral.com/I47I-230X/7/44

(c) 2007 Cindoruk et al; licensee BioMed Central Ltd.

This is an Open Access article distributed under the terms of the Creative Commons Attribution License (http://creativecommons.org/licenses/by/2.0), which permits unrestricted use, distribution, and reproduction in any medium, provided the original work is properly cited.

\section{Abstract}

Background: Peroxisome proliferators-activated receptor alpha (PPAR $\alpha$ ) activation modulates cholesterol metabolism and suppresses bile acid synthesis. This study aims to evaluate the effect of short-term administration of fenofibrate, a PPAR $\alpha$ agonist, on proinflammatory cytokines, apoptosis, and hepatocellular damage in cholestasis.

Methods: Forty male Wistar rats were randomly divided into four groups: I = sham operated, II = bile duct ligation (BDL), III = BDL + vehicle (gum Arabic), IV = BDL + fenofibrate $(100 \mathrm{mg} / \mathrm{kg} /$ day). All rats were sacrificed on $7^{\text {th }}$ day after obtaining blood samples and liver tissue. Total bilirubin, aminotransferase (AST), alanine aminotransferase (ALT) and alkaline phosphatase (ALP), gammaglutamyl transferase, (GGT), tumor necrosis factor alpha (TNF- $\alpha$ ), interleukin I beta (IL-I $\beta$ ), and total bile acid (TBA) in serum, and liver damage scores; portal inflammation, necrosis, bile duct number, in liver tissue were evaluated. Apoptosis in liver was also assessed by immunohistochemical staining.

Results: Fenofibrate administration significantly reduced serum total bilirubin, AST, ALT, ALP, and GGT, TNF- $\alpha$, IL-I $\beta$ levels, and TBA $(P<0.0$ I). Hepatic portal inflammation, hepatic necrosis, number of the bile ducts and apoptosis in rats with BDL were more prominent than the shamoperated animals $(P<0.01)$. PPAR $\alpha$ induction improved all histopathologic parameters $(P<0.01)$, except for the number of the bile duct, which was markedly increased by fenofibrate therapy $(P<$ $0.01)$.

Conclusion: Short-term administration of fenofibrate to the BDL rats exerts beneficial effects on hepatocellular damage and apoptosis. 


\section{Background}

Cholestatic liver diseases are characterized by impaired hepatocellular secretion of bile, resulting in intracellular accumulation of bilirubin, bile acids and cholesterol. Bile duct ligation (BDL) causes complete blockage of cholesterol excretion, and it is well known that hyperlipidemia develops in obstructive jaundice. Bile acids are the major products of cholesterol metabolism in the liver, and act as physiological detergents that facilitate absorption, transport, disruption of lipid-soluble fats and vitamins; furthermore it also aids in the excretion of lipids. Retention and accumulation of toxic, hydrophilic bile salts stimulates the production of proinflammatory cytokines and enhances apoptosis which leads to hepatocellular damage $[1,2]$. Apoptosis is an integral part of many biological processes, including embryonic development, metamorphosis, hormone-dependent atrophy, and in chemicalinduced cell death $[3,4]$.

Fibrates are frequently used in the treatment of hyperlipidemia and are generally effective in lowering elevated plasma triglyceride and cholesterol levels [5]. They exert multiple effects on lipid metabolism pathways by activating peroxisome proliferator-activated receptor alpha (PPAR $\alpha)$, a specific ligand inducible transcription factor which controls gene expression through peroxisome proliferators response elements (PPREs) [6]. PPAR $\alpha$ agonists modulate cholesterol metabolism pathways in the liver [7]. Indeed, fibrates suppress bile acid synthesis, the major pathway of cholesterol elimination from the body $[8,9]$. Induction of PPAR $\alpha$ increases the size and the number of hepatocytes within the first few days of exposure. During this time, spontaneous hepatocyte apoptosis is suppressed within the intact liver [10]. Rodent primary hepatocytes successfully recapitulate the early response to PP exposure observed in vivo. This shows suppression of spontaneous apoptosis after PP exposure, as well as apoptosis induced TGF beta and fas is PPAR $\alpha$ dependent $[11,12]$. Therefore, long-term induction of PPAR $\alpha$ results in hepatomegaly and increases hepatocellular hyperplasia and consequently carcinogenesis in liver $[10,12]$. PPAR $\alpha$ activation leads to the enhanced apoptosis in normal liver $[13,14]$. But its effects on apoptosis in cholestatic liver are unknown.

Though the reduction of bile salts by induction of PPAR $\alpha$ has been evaluated in variety of studies, there is no evidence about the effects of short-term PPAR $\alpha$ induction in cholestatic liver. It can be assumed that bile salt retention and altered cholesterol metabolism play central roles in obstructive jaundice. Therefore, PPAR $\alpha$ induction may attenuate hepatocellular damage. The aim of the present study is to investigate the effects of short term fenofibrate treatment, a PPAR $\alpha$ receptor agonist, on hepatocellular damage, oxidative stress, apoptosis and the levels of proinflammatory cytokines.

\section{Methods}

\section{Ethics and Animals}

The study was performed on forty male Wistar Albino rats weighing 230-270 g, and conducted following the experimental protocol approved by Committee for Research and Animal Ethics of Gazi University. Animals were housed in stainless steel cages under controlled temperature and humidity, and with 12-hour dark/light cycles. All rats were allowed at the least one week of adaptation to the laboratory before the experimental procedure began. They were allowed free access to a commercial standard chow and water ad libitum. Rats were randomly assigned to four experimental groups each containing ten rats as follows:

Group 1 (Sham, $\mathbf{n}=10$ ): underwent a sham operation.

Group 2 (BDL, $\mathbf{n}=10)$ : had common bile duct ligation (BDL)

Group 3 (BDL + vehicle, $\mathbf{n}=10)$ : had BDL and administered gum arabic by gavage.

Group $4(\mathrm{CBDL}+$ fenofibrate, $\mathrm{n}=10)$ : had BDL and given fenofibrate by gavage.

Sham-operated rats served as a control group.

\section{Operative Procedures}

Each rat was weighed and anesthetized by intraperitoneal administration of $40 \mathrm{mg} / \mathrm{kg}$ ketamine (Ketalar ${ }^{\oplus}$, Parke Davis, Eczacýbasi, Istanbul, Turkey) and $5 \mathrm{mg} / \mathrm{kg}$ xylocaine (Rompum ${ }^{\oplus}$, Bayer AG, Leverkusen, Germany). The abdomen was shaved and disinfected with $10 \%$ povidone iodine. Following a midline incision, the common bile duct was exposed and a double-ligature with 5-0 silk was performed and the bile duct was sectioned between the ligatures. In the sham-operated animals the common bile duct ligation (BDL) was freed from surrounding soft tissue without ligation and transaction. Abdominal incision was closed in layers with 4-0 dexon and 2-0 nylon. Animals received standard rat chow during experiment.

\section{Preparation and Administration of Fenofibrate}

Fenofibrate (Lipofen, Nobel Drug Industry, Istanbul) was dissolved 3\% aqueous sterile solution of gum Arabic. Fenofibrate solution was administered as a single dose of $100 \mathrm{mg} / \mathrm{kg}$ via gavage for the first to sixth postoperative days [15]. The oral dose and duration of the gum arabic of group 3 was the same used in treated groups. 


\section{Harvest of Tissue and Blood Samples}

Seven days after the surgical procedures the animals were anesthetized, and relaparotomy was performed. After blood samples were drawn, the liver was carefully dissected out from its attachment, and totally excised. All rats were then sacrificed by hemorrhage. The blood samples were kept at $-80^{\circ} \mathrm{C}$ for biochemical analyses which were duplicates. Liver tissue was fixed in 10\% neutral phosphate-buffered formalin, and then embedded in paraffin wax.

\section{Blood Biochemistry}

The serum bilirubin level was determined with a Cobas Bio (Hoffman La Roche, Basel, Switzerland) using direct bilirubin test (Hoffman La Roche, Basel, Switzerland). The serum activity of aminotransferase (AST), alanine aminotransferase (ALT), alkaline phosphatase (ALP) gamma-glutamyl transferase, (GGT were measured by using commercially available kits (Boehringer, Mannheim, Germany). Total bile acid (TBA) was determined using an analytical kit from Sigma, USA with a 747 automatic biochemistry analyzer.

Serum Tumor Necrosis Factor- $\alpha$ and Interleukin-I $\beta$ Assay In order to determine the levels of TNF- $\alpha$ and IL-1 $\beta$, a commercial solid phase sandwich ELISA from Biosource International (Camarillo, CA, USA) was used. TNF- $\alpha$ and IL-1- $\beta$ levels were determined from a standard curve for recombinant TNF- $\alpha$ and IL-1 $\beta$; and concentrations were expressed as $\mathrm{pg} / \mathrm{ml}$. The ELISA detection limit for TNF- $\alpha$ and IL- $1 \beta$ were $3 \mathrm{pg} / \mathrm{ml}$.

\section{Determination of Tissue MDA}

Tissue MDA assays were performed according to Ohkawa et al. [16]. Briefly, MDA, the product of lipid peroxidation, reacts with thiobarbituric acid under acidic conditions at $95^{\circ} \mathrm{C}$ to form a pink-colored complex with an absorbance at $532 \mathrm{~nm}$. 1,1,3,3-Tetraethoxypropane was used as the standard. The results are expressed as $\mathrm{nmol} / \mathrm{mg}$ protein.

\section{Assessment of Apoptosis}

Apoptosis in liver tissues was detected by measuring the appearance of apoptotic bodies with terminal deoxynucleotidyl transferase-mediated deoxyuridine triphosphate nick-end labeling (TUNEL) assay using the ApopTag peroxidase kit (Invitrogen, Carlsbad, CA), and by pathological quantification of apoptotic foci. Approximately 3000 average cells were counted per sample. This specific assay uses terminal deoxynucleotidyl transferase to attach biotinylated deoxyuridine triphosphate to free 3'-OH DNA ends. Liver tissue sections $(5 \mu \mathrm{m})$ were prepared using a microtome and placed on glass slides. The sections were deparaffinized in xylene, dehydrated in ethanol, and then incubated with proteinase $\mathrm{K} 20 \mu \mathrm{m} / \mathrm{ml}$ in PBS for $20 \mathrm{~min}$ utes at room temperature. After rinsing the specimen twice with PBS, the sections were processed following the instructions of a commercial kit (Dead End Colorimetric Apoptosis Detection System; Promega, Madison, WI, U.S.A.). Sections were stained with streptavidin-horseradish peroxidase conjugate, and then counterstained with hematoxylin. The peroxidase- positive cells were identified morphometrically by brown staining nuclei. The numbers of TUNEL-positive cells were counted in 10 random microscopic fields $(400 \times)$.

\section{Histopathology}

Liver tissues were fixed in $40 \mathrm{mg} / \mathrm{ml}$ formaldehyde and were embedded in paraffin. For histopathological evaluation, 4- $\mu \mathrm{m}$ slides were stained with hematoxylin-eosin, Masson's trichrom, Periodic acid-Schiff (PAS), and Hall's stain for bile. Sections were scored by an independent observer blinded to the experimental protocol. The following lesions were scored according to Modified Histological Activity Index: $[17,18]$ portal inflammation, focal necrosis, confluent necrosis, interface hepatitis, and focal inflammation. The numbers of biliary canals in five portal sites for each section were also noted.

\section{Statistics}

All results were analyzed and are given as the mean \pm standard deviation (SD). Comparisons among multiple groups were performed using Kruskal- Wallis test. If there was a significant difference between groups, further paired comparisons were done by using Mann-Whitney U test. We have divided conventional significant $p$ value $(0.05)$ by the total number of groups $(n=4)$ to find the true $p$ value for this study. For this reason, the significant value of $\mathrm{p}$ in this study is accepted as below $0.0125(0.05$ divided by $4=0.0125$ )

\section{Results}

No deaths were observed during the experiment. All animals with BDL were obviously jaundiced 3 days after the operation. The jaundice was confirmed by measuring the serum total bilirubin concentration on $7^{\text {th }}$ day after BDL (Table 1). BDL results in severe bile acid-induced liver injury. BDL is associated with intrahepatic bile acid overload and consequent liver injury.

\section{BDL-Induced Hepatopathology and Cholestasis}

Serum AST, ALT, GGT, ALP, and TBA levels were significantly elevated in all animals in which BDL was performed when compared to sham-operated rats, and the same parameters were considerably lower in the fenofibrate group than other BDL groups $(P<0.01)$. No significant difference was observed in the biochemical parameters between the control and BDL-vehicle groups. Similarly, although serum direct bilirubin levels were significantly elevated in all BDL animals compared with 
Table I: Change in concentrations of laboratory data (mean \pm SD)*

\begin{tabular}{|c|c|c|c|c|}
\hline & Sham & BDL & BDL + vehicle & BDL + fenofibrate \\
\hline Bilirubin (mg/dl) & $0.68 \pm 0.17$ & $9.05 \pm 2.24^{\mathrm{a}}$ & $8.98 \pm 2.78^{a}$ & $6.02 \pm 1.56^{a, b, c}$ \\
\hline ALT (IU/L) & $45.7 \pm 9.7$ & $115.7 \pm 16.5^{a}$ & $117.4 \pm 20.2^{\mathrm{a}}$ & $82.7 \pm 12.0^{a, b, c}$ \\
\hline AST (IU/I) & $78.1 \pm 9.6$ & $142.8 \pm 17.8^{a}$ & $147.7 \pm 24.0^{a}$ & $99.4 \pm 13.6^{a, b, c}$ \\
\hline GGT (IU/I) & $7.7 \pm 2.7$ & $37.8 \pm 8.0^{\mathrm{a}}$ & $34.4 \pm 13.1^{a}$ & $26.4 \pm 6.2^{\mathrm{a}, \mathrm{b}, \mathrm{c}}$ \\
\hline ALP (IU/L) & $95.9 \pm 19.4$ & $408.2 \pm 42.4^{a}$ & $416.0 \pm 62.6^{a}$ & $381.6 \pm 36.9^{\mathrm{a}, \mathrm{b}}$ \\
\hline TBA $(\mu \mathrm{mol} / \mathrm{ml})$ & $3.2 \pm 1.2$ & $34.3 \pm 3.8^{a}$ & $35.7 \pm 2.9^{a}$ & $26.7 \pm 4 .\left.\right|^{a, b, c}$ \\
\hline TNF- $\alpha(p g / m L)$ & $6.2 \pm 2.57$ & $45.7 \pm 4.6 \mathrm{I}^{\mathrm{a}}$ & $43.8 \pm 5.86^{a}$ & $32.7 \pm 5.6^{a, b, c}$ \\
\hline $\mathrm{IL}-\mathrm{I} \beta(\mathrm{pg} / \mathrm{mL})$ & $7.3 \pm 3.9$ & $130.3 \pm 16.6^{\mathrm{a}}$ & $128.3 \pm 23.9^{a}$ & 83.2. $\pm 11.3^{\mathrm{a}, \mathrm{b}, \mathrm{c}}$ \\
\hline $\begin{array}{l}\text { Tissue MDA levels (nmol/ } \\
\text { mg protein) }\end{array}$ & $0.5 \pm 0.2$ & $4.9 \pm 1.2^{\mathrm{a}}$ & $4.8 \pm 0.9 \mathrm{a}$ & $2.1 \pm 0.4^{a, b, c}$ \\
\hline
\end{tabular}

\footnotetext{
*Comparisons between groups were done by using Kruskal-Wallis test. Paired comparisons are done by using Mann-Whitney $U$ test. ap $<0.0$ I versus sham group (Mann-Whitney $U$ after Kruskal-Wallis test)

$\mathrm{b} P<0.0 \mathrm{I}$ as compared to $\mathrm{BDL}$ groups (Mann-Whitney $U$ after Kruskal-Wallis test)

$c P<0.01$ as compared to $B D L+$ vehicle groups (Mann-Whitney $U$ after Kruskal-Wallis test)
}

shams, it was lower after BDL in PPAR $\alpha$ activated rats than other BDL's $(P=0.01)$.

\section{Proinflammatory Cytokines}

Serum TNF- $\alpha$ and IL- $1 \beta$ levels in animals with BDL were significantly higher than in the sham group $(P<0.01$, Table 1). There were no significant differences in terms of the cytokines between the BDL and BDL-vehicle groups. Fenofibrate treatment significantly decreased the serum TNF- $\alpha$ and IL- $1 \beta$ levels in rats with BDL $(P<0.01$, Table $1)$.

\section{Tissue MDA levels}

The levels of MDA, which is the last product of oxidative injury, were significantly increased after BDL when compared with sham group $(P<0.001)$. Fenofibrate treatment decreased the MDA levels significantly when compared with BDL and BDL-vehicle groups $(P=0.01$, Table 1$)$.

\section{Histopathologic Examination}

Histopathological examination showed that portal inflammation, interface hepatitis, lobar and confluent necrosis and bile duct number in rats which underwent
BDL were significantly higher than in sham-operated rats. Except the bile duct number, all histopathologic parameters in rats administrated fenofibrate markedly decreased in comparison to control rats and BDL-vehicle. It was apparent that fenofibrate treatment caused significant increase in number of bile ducts $(P<0.01$, Table 2, Figure $1)$. The reduction of hepatic necrosis and increase in the number of bile duct suggest that fenofibrate has regenerative effects.

\section{Apoptosis}

Hepatocyte apoptosis in the animals with BDL is significantly higher than in sham group $(P<0.001)$. PPAR $\alpha$ activation significantly decreased apoptosis in rats with BDL compared to control and BDL-vehicle groups $(P<0.01$, Figure 2).

\section{Discussion}

The administration of peroxisome proliferators results in a marked increase in the number and size of peroxisomes and size of the liver $[5,10,11]$. Furthermore; long-term administration of peroxisome proliferators causes hepatocellular carcinoma in rats and mice $[5,12,19]$. Long-term

Table 2: Change in histopathologic scores (mean \pm SD)*

\begin{tabular}{|c|c|c|c|c|}
\hline & Sham & BDL & BDL + vehicle & BDL + fenofibrate \\
\hline Portal inflammation & 0 & $3.2 \pm 0.2^{\mathrm{a}}$ & $3.1 \pm 0.7 \mathrm{a}$ & $2.0 \pm 0.5^{\mathrm{a}, \mathrm{b}, \mathrm{c}}$ \\
\hline Interface hepatitis & 0 & $1.8 \pm 0.7^{a}$ & $1.7 \pm 0.9 \mathrm{a}$ & $1.3 \pm 0.6^{\mathrm{a}, \mathrm{b}, \mathrm{c}}$ \\
\hline Confluent necrosis & 0 & $2.2 \pm 0 . .^{\mathrm{a}}$ & $2.1 \pm 0.9^{a}$ & $1.1 \pm 0.2^{\mathrm{a}, \mathrm{b}, \mathrm{c}}$ \\
\hline Lobar necrosis & 0 & $3.0 \pm 0.9 \mathrm{a}$ & $2.9 \pm 0.7^{a}$ & $2.1 \pm 0.8^{\mathrm{a}, \mathrm{b}, \mathrm{c}}$ \\
\hline $\begin{array}{l}\text { Bile duct number } / 5 \text { portal } \\
\text { field }\end{array}$ & $3.5 \pm 1.3$ & $18.9 \pm 8.0^{a}$ & $17.5 \pm 7 .\left.\right|^{\mathrm{a}}$ & $23.2 \pm I I . I^{a, b, c}$ \\
\hline
\end{tabular}

*Comparisons between groups were done by using Kruskal-Wallis test. Paired comparisons are done by using Mann-Whitney $U$ test.

ap $<0.01$ versus sham group (Mann-Whitney $U$ )

bP $<0.0$ I as compared to BDL group (Mann-Whitney $U$ )

$c P<0.01$ as compared to BDL + vehicle group (Mann-Whitney $U$ ) 


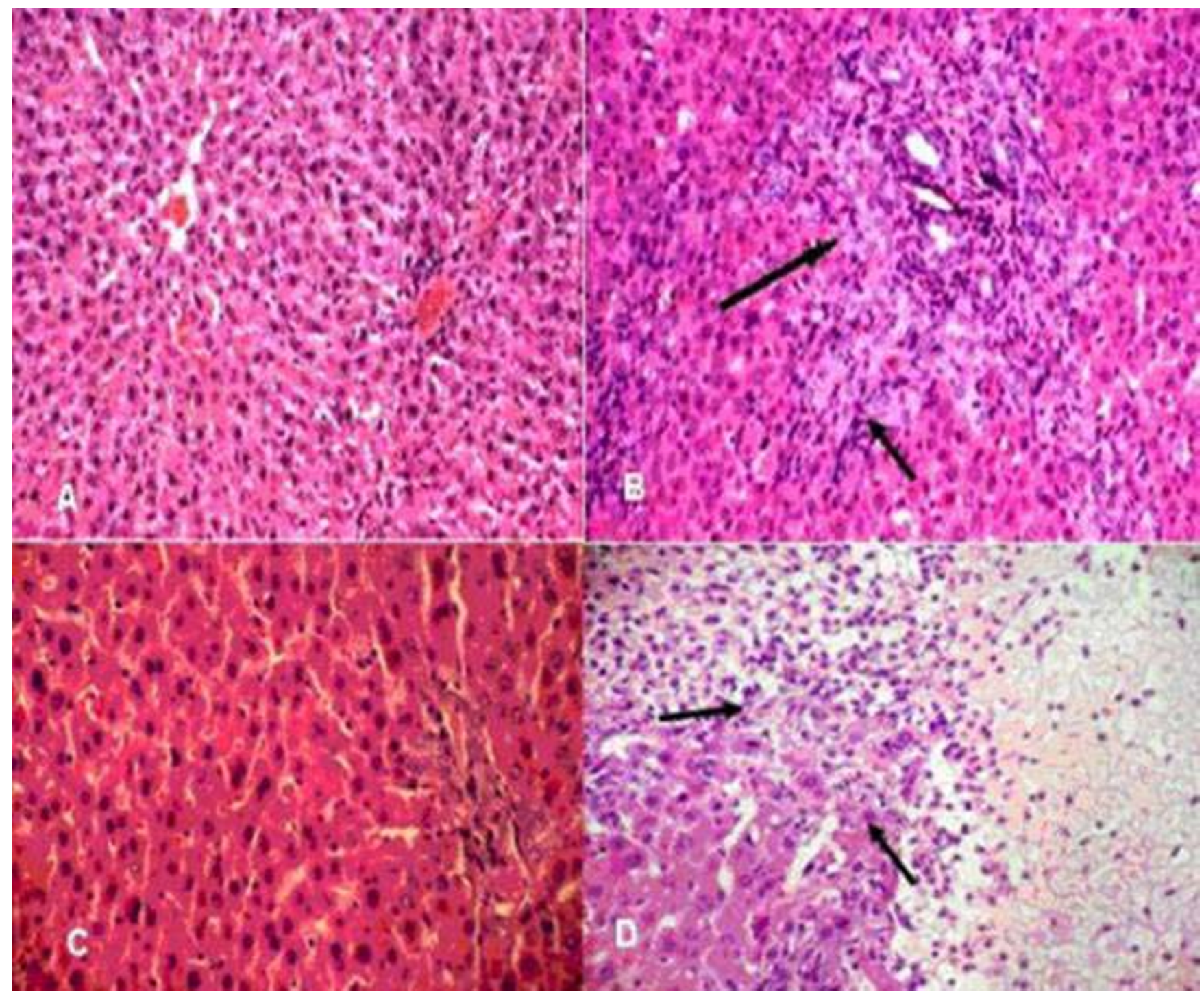

Figure I

$H$ \& E-stained liver sections of sham operated $(A)$ and BDL $(B)$ rats demonstrate bile-duct dilation, polymorphonuclear cell infiltrate, bile-duct proliferation (arrow, HE $\times 20$ ), (C) markedly inflammation, and (D) necrosis (arrow, HE $\times 200$ ).

pharmacologic exposure of patients to the hypolipidemic drugs gemfibrosil, and clofibrate, which are potent rodent peroxisome proliferators, has not revealed any increased risk of hepatocellular cancer or others $[5,20]$. For this reason, we designed this experiment in order to evaluate the short term effects of fenofibrate treatment for its effects in decreasing bile production and cholesterol synthesis.

The most important factors for obstructive jaundice are accumulation of bilirubin, bile acids, and cholesterol in liver [1]. Bile acid synthesis has been reported to increase after BDL in animals. Weis and Dietschy [21] showed that after acute bile duct obstruction, cholesterol synthesis increased five fold. It has been demonstrated that choles- terol $7 \alpha$-hydroxylase activities, catalyzes the first and ratelimiting step in the major pathway for bile acid biosynthesis from cholesterol homeostasis, increased significantly after obstructive jaundice [22]. Fibrates inhibit bile acid synthesis, the major pathway of cholesterol elimination from the body, by reducing cholesterol $7 \alpha$-hydoxylase gene (CYP7A1) and sterol 27-hydoxylase gene (CYP27A1) expression in rodents [8] and 7 $\alpha$-hydroxylation rate in humans [9]. Le Jossic-Corcos et al. [7] showed that fibrates decreased cholesterol efflux, cholesterol conversion into bile acids and cholesterol ester storage in rat hepatocytes. In our study, TBA levels in fenofibrate treatment group were significantly lower than control group. In addition, the fibrates exerted their effects through low- 


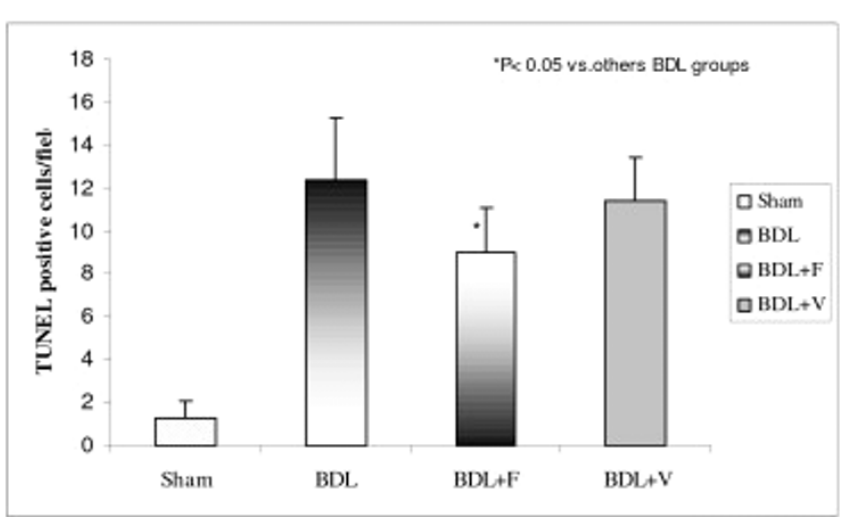

Figure 2

TUNEL-positive cells per field. Apoptosis in rats with BDL was significantly higher than sham-operated rats $(P<0.0$ I, Kruskal-Wallis test). $\mathrm{BDL}=$ Bile duct ligation, $\mathrm{BDL}+\mathrm{F}=\mathrm{BDL}$ + fenofibrate, $B D L+V=B D L+$ vehicle.

ering serum total bilirubin levels $(P<0.01)$. It's well known that fenofibrates increases the conjugation of bilirubin and glucoronoid. Fenofibrates might have decreased the direct bilirubin levels.

In our study, liver enzymes increased after BDL. Although fenofibrate treatment decreased the levels of these enzymes, the levels have still remained high when compared with sham group. This might be a result of short treatment period with fenofibrate.

In histological examination, fenofibrate mediated PPAR $\alpha$ activation significantly decreased lobar and confluent necrosis. Nevertheless, histological parameters remained high when compared to sham operated group.

Hepatocellular apoptosis is a common result of accumulation of bile, bile salts and cholesterol [1-3]. Apoptosis occurs at a constant rate in the liver and this process is believed to be a means by which old and damaged cells are eliminated. If not eliminated, cells having DNA damage could potentially become transformed by further mitogenic stimulation and DNA mutations [22,23]. Nevertheless; inappropriate apoptosis plays an important role in many diseases. In our study enhanced apoptosis is observed following BDL.

There are various studies stating that PPAR $\alpha$ activation may increase [14] or decrease apoptosis [10,11]. On the other hand, according to our knowledge, the effects of fenofibrate on enhanced apoptosis in the setting of cholestasis have not been studied. Our study shows that PPAR $\alpha$ activation decreases apoptosis in an experimental model of cholestasis. PPAR $\alpha$ agonists activate nuclear factor kappa B (NF- $\mathrm{B})$ in the rat and mouse liver, but not in the hamster. Rats and mice are sensitive to hepatocellular hyperplastic effects of PPAR $\alpha$ ligands. It has also been shown that NF- $\kappa \mathrm{B}$ has an anti-apoptotic activity in several cell types, including hepatic cell lines. Cosulich et al. $[24,25]$ demonstrated that the response of NF- $\kappa B$ to peroxisome proliferators by inhibiting apoptosis in hepatocytes was provided by use of a dominant negative form of a subunit IkappaB kinase (IKK)-2 complex that is critical for activity of the $\mathrm{I} \kappa \mathrm{B}$ kinase. Ductal proliferation is the one of the changes occurred in obstructive jaundice [26]. In our study the number of bile ducts significantly increased in rats with obstructive jaundice. The number of bile ducts increased with fenofibrate treatment. Activation of PPAR- $\alpha$ might have affected the tolerability of cholestasis in the increase of the number of bile ducts which may due to hepatocellular proliferation.

Proinflammatory cytokines, such as TNF- $\alpha$, and IL-1 beta enhance liver damage in cholestasis. In our study, fenofibrate treatment resulted in a significant decrease in proinflammatory cytokine levels. Portal inflammation and interface hepatitis significantly increased 7 day following the BDL. At the same time serum levels of TNF- $\alpha$ and IL- 1 $\beta$ in rats with obstructive jaundice showed significant increases. Fenofibrate treatment decreased histopathological findings of inflammation, and decreased the cytokine levels significantly. PPAR $\alpha$ has been demonstrated to act as a negative regulator of genes involved in the inflammatory response by antagonizing the activity of transcription factors, such as activated protein- 1 expression, partly by direct interaction with proteins such as p65 and c-Jun [27]. The induction of PPAR $\alpha$ may have resulted in decreased inflammation through altered acute phase reactants.

Increased activation of Kupffer cells after obstructive jaundice affects not only inflammation but also the oxidative injury. MDA which is the end product of oxidative injury and lipid peroxidation increased in obstructive jaundice. In our study MDA levels significantly increased after BDL, also. This increase significantly decreased after fenofibrate treatment. Oxidative injury has decreased due to the increased level of antioxidant enzymes [28] as a result of PPAR- $\alpha$ activation.

\section{Conclusion}

Short-term induction of nuclear receptor PPAR $\alpha$ by fenofibrate decreases hepatocellular necrosis, oxidative damage and inflammation and consequently hepatic damage. Furthermore, although these results suggest a beneficial effect of fenofibrate, the administration of these drugs in the treatment of cholestatic patients still remains to be a matter of debate [29-31] and needs further experimental and clinical studies. Especially; the alteration in the bile production and induction of bile duct proliferation are 
important points that the researchers should pay attention for the use of these drugs in the treatment of obstructive jaundice.

\section{Competing interests}

The author(s) declare that they have no competing interests.

\section{Authors' contributions}

$\mathrm{MC}, \mathrm{MK}$ and $\mathrm{TK}$ participated in the conception and design of the study, preparation of the manuscript and practical performance. BS carried out collection and analysis of data and practical performance. SU performed critical review process of the manuscript. OA carried out biochemical study. MA and OE carried out pathological examination. All authors read and approved the manuscript.

\section{References}

I. Trauner M, Meierer PJ, Boyer JL: Molecular pathogenesis of cholestasis. New Eng J Med 1998, 39:1217-1227.

2. Miyoshi H, Rust C, Roberts PJ, Burgart LJ, Gores GJ: Hepatocyte apoptosis after bile duct ligation in the mouse involves Fas. Gastroenterology 1999, I 1 7:669-677.

3. Allen RT, Hunter WJ 3rd, Agrawal DK: Morphological and biochemical characterization and analysis of apoptosis. J Pharm Toxicol Methods 1997, 37:215-228.

4. Patel T, Bronk SF, Gores GJ: Increases of intracellular magnesium promote glycodeoxycholate-induced apoptosis in rat hepatocytes. J Clin Invest 1994, 94:2183-2192.

5. Gonzalez FJ, Peters JM, Cattley RC: Mechanism of action of the nongenotoxic peroxisome proliferators: role of the peroxisome proliferator-activator receptor alpha. J Natl Cancer Inst 1998, 18:1702-1719.

6. Zimetbaum P, Frishman WH, Kahn S: Effects of gemfibrozil and other fibric acid derivatives on blood lipids and lipoproteins. I Clin Pharmacol 1991, 31:25-37.

7. Le Jossic-Corcos C, Duclos S, Ramirez LC, Zaghini I, Chevillard G, Martin P, Pineau T, Bournot P: Effects of peroxisome proliferator-activated receptor alpha activation on pathways contributing to cholesterol homeostasis in rat hepatocytes. Biochim Biophys Acta 2004, 1683:49-58.

8. Post SM, Duez H, Gervois PP, Staels B, Kuipers F, Princen HM Fibrates suppress bile acid synthesis via peroxisome proliferator-activated receptor-alpha-mediated downregulation of cholesterol 7alpha-hydroxylase and sterol 27-hydroxylase expression. Arterioscler Thromb Vasc Biol 200I, 2 I: I840-I845.

9. Stahlberg D, Reihner E, Rudling M, Berglund L, Einarsson K, Angelin $B$ : Influence of bezafibrate on hepatic cholesterol metabolism in gallstone patients: reduced activity of cholesterol 7 alpha-hydroxylase. Hepatology 1995, 21:1025-1030.

10. James NH, Soames AR, Roberts RA: Suppression of hepatocyte apoptosis and induction of DNA synthesis by the rat and mouse hepatocarcinogen diethylhexylphlathate (DEHP) and the mouse hepatocarcinogen I,4-dichlorobenzene (DCB). Arch Toxicol 1998, 72:784-790.

II. Hasmall SC, James NH, Macdonald N, Gonzalez FJ, Peters JM, Roberts RA: Suppression of mouse hepatocyte apoptosis by peroxisome proliferators: role of PPAR alpha and TNF alpha. Mutat Res 2000, 448;: 193-200.

12. Gill JH, James NH, Roberts RA, Dive C: The non-genotoxic hepatocarcinogen nafenopin suppresses rodent hepatocyte apoptosis induced by TGFbetal, DNA damage and Fas. Carcinogenesis 1998, 19:299-304.

13. Gonzalez F]: The peroxisome proliferator-activated receptor alpha (PPARalpha): role in hepatocarcinogenesis. Mol Cell Endocrinol 2002, 193:71-9.

14. Xiao S, Anderson SP, Swanson C, Bahnemann R, Voss KA, Stauber AJ, Corton JC: Activation of peroxisome proliferator-activated receptor alpha enhances apoptosis in the mouse liver. Toxicol Sci 2006, 92:368-77.

15. Montanaro MA, Bernasconi AM, Gonzalez MS, Rimoldi OJ, Brenner RR: Effects of fenofibrate and insulin on the biosynthesis of unsaturated fatty acids in streptozotocin diabetic rats. Prostaglandins Leukot Essent Fatty Acids 2005, 73:369-78.

16. Ohkawa $\mathrm{H}$, Ohishi $\mathrm{N}$, Yagi $\mathrm{K}$ : Assay for lipid peroxides in animal tissues by thiobarbituric acid reaction. Anal Biochem 1979, 95:35I-358

17. Knodell RG, Ishak KG, Black WC, Chen TS, Craig R, Kaplowitz N, Kiernan TW, Wollman J: Formulation and application of a numerical scoring system for assessing histological activity in asymptomatic chronic active hepatitis. Hepatology 198I, I:43I-5.

18. Ishak K, Baptista A, Bianchi L, Callea F, De Groote J, Gudat F, Denk $\mathrm{H}$, Desmet $\mathrm{V}$, Korb G, MacSween RN: Histological grading and staging of chronic hepatitis. J Hepatol 1995, 22:696-9.

19. Reddy JK, Rao MS: Peroxisome proliferation and hepatocarcinogenesis. IARC Sci Publ 1992, I 16:225-235.

20. Frick $M H$, Elo $O$, Haapa $K$, Heinonen OP, Heinsalmi P, Helo P, Huttunen JK, Kaitaniemi P, Koskinen P, Manninen V: Helsinki Heart Study: primary-prevention trial with gemfibrozil in middleaged men with dyslipidemia. Safety of treatment, changes in risk factors, and incidence of coronary heart disease. N EnglJ Med 1987, 317:1237-1245.

21. Weis HJ, Dietschy JM: Presence of an intact cholesterol feedback mechanism in the liver in biliary stasis. Gastroenterology 1971, 61:77-84.

22. Danielsson $\mathrm{H}$ : Effect of biliary obstruction on formation and metabolism of bile acids in rat. Steroids 1973, 22:567-79.

23. Lowe SW, Lin AW: Apoptosis in cancer. Carcinogenesis 2000, $21: 485-95$.

24. Cosulich SC, James NH, Needham MR, Newham PP, Bundell KR, Roberts : A dominant negative form of IKK2 prevents suppression of apoptosis by the peroxisome proliferator nafenopin. Carcinogenesis 2000, 21:1757-60.

25. Kleemann R, Verschuren L, de Rooji B], Lindeman J, de Maat MM, Szalai AJ, Princen HMG, Kooistra T: Evidence for anti-inflammatory activity of stains and PPAR $\alpha$ activators in human C-reactive protein transgenic mice in vivo and in cultured human hepatocytes in vitro. Blood 2004, 103:4188-94.

26. Anderson SP, Dunn CS, Cattley RC, Corton JC: Hepatocellular proliferation in response to a peroxisome proliferator does not require TNFalpha signaling. Carcinogenesis 200I, 22: $|843-5|$.

27. Corton JC, Fan LQ, Brown S, Anderson SP, Bocos C, Cattley RC, Mode A, Gustafsson JA: Down-regulation of cytochrome P450 2C family members and positive acute-phase response gene expression by peroxisome proliferator chemicals. Mol Pharmacol 1 998, 54:463-473.

28. Toyama $\mathrm{T}$, Nakamura $\mathrm{H}$, Harano $\mathrm{Y}$, Yamauchi N, Morita A, Kirishima T, Minami M, Itoh Y, Okanoue T: PPARalpha ligands activate antioxidant enzymes and suppress hepatic fibrosis in rats. Biochem Biophys Res Commun 2004, 324:697-704.

29. Dohmen K, Mizuta T, Nakamuta M, Shimohashi N, Ishibashi H, Yamamoto K: Fenofibrate for patients with asymptomatic primary biliary cirrhosis. World J Gastroenterol 2004, 10:894-898.

30. Ho CY, Kuo TH, Chen TS, Tsay SH, Chang FY, Lee SD: Fenofibrateinduced acute cholestatic hepatitis. J Chin Med Assoc 2004, 67:245-247.

31. Ohira $H$, Sato $Y$, Ueno $T$, Sata $M$ : Fenofibrate treatment in patients with primary biliary cirrhosis. Am J Gastroenterol 2002, 97:2147-2। 49 .

\section{Pre-publication history}

The pre-publication history for this paper can be accessed here:

\section{http://www.biomedcentral.com/1471-230X/7/44/pre} pub 